\title{
Effect of supplementation with core homeopathic on the serum immunological profile of pregnant ewes and lambs
}

\author{
Efeito da suplementação com complexo homeopático no \\ perfil imunológico sérico de ovelhas gestantes e cordeiros
}

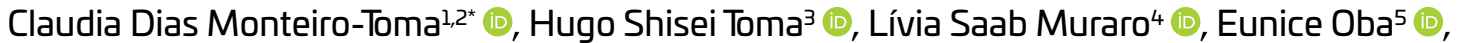 \\ Jéssica Núbia da Silva Almeida ${ }^{(1)}$, Armando de Mattos Carvalho ${ }^{6}$ (1), \\ Fabiola Cristiane de Almeida Rêgo ${ }^{7}$ (D), Marcelo Diniz dos Santos ${ }^{1,4}$ (i)
}

\begin{abstract}
Few information is available about the optimal period for colostrum absorption in the bowel of newborn lambs. The aim of the current study was to investigate the effects of using supplementation with commercial core homeopathic during pregnancy and early lactation on 18 pregnant Santa Inês ewes presenting body condition score $\geq 2.5$. Pregnant animals were randomly divided in two groups; one was used as control (control group) and the other was supplemented on a daily basis with $30 \mathrm{~g}$ of homeopathic product with Natrum muriaticum $10^{-60}$, Calcium carbonicum $10^{-30}$, Silicea terra $10^{-400}$ and Hypothalamus $10^{-30}$ per animal, mixed to the concentrate during pregnancy and early lactation (treatment group). The Total Protein (TP) and globulin (GLB) values found in ewes and lambs belonging to the treatment group were higher than and different from those recorded for the control group. The serum albumin (ALB) concentration did not differ between groups of ewes but was different in lambs. TP and GLB evolution in lambs and ewes throughout the seven experimental days showed the animals in the treatment group trend to present higher TP and GLB values in all experimental periods; supplemented animals showed trend to progressive increase in both variables until day 3; whereas nonsupplemented animals showed such trend until day 2 (when they reached their peak). The commercial core homeopathic to the animals during pregnancy and early lactation resulted in higher TP and GLB concentrations in the serum samples collected from ewes and lambs.
\end{abstract}

KEYWORDS: Globulin; Homeopathy; Immunoglobulin; Immunity; Ovine.

RESUMO: Poucas informações estão disponíveis sobre o período ideal para a absorção do colostro no intestino de neonatos ovinos. O objetivo do presente estudo é investigar os efeitos da suplementação com complexo homeopático comercial durante a gestação e início da lactação em 18 ovelhas Santa Inês gestantes com escore de condição corporal $\geq 2,5$. Os animais gestantes foram divididos aleatoriamente em dois grupos; um controle (grupo controle) e outro suplementado diariamente com $30 \mathrm{~g}$ de produto homeopático com Natrum muriaticum $10^{-60}$, Calcium carbonicum $10^{-30}$, Silicea terra $10^{-400}$ and Hypothalamus $10^{-30}$ por animal, misturado ao concentrado durante a gestação e início da lactação (grupo tratamento). Os valores de Proteína Total (PT) e globulina (GLB) encontrados em ovelhas e cordeiros pertencentes ao grupo tratamento foram superiores e diferentes dos registrados para o grupo controle. A concentração de albumina sérica (ALB) não diferiu entre os grupos de ovelhas, mas foi diferente nos cordeiros. A evoluçáo de PT e GLB em cordeiros e ovelhas ao longo dos 7 dias experimentais demonstrou que os animais do grupo tratamento tendem a apresentar maiores valores de PT e GLB em todo o período experimental; os animais suplementados apresentaram tendência de aumento progressivo em ambas as variáveis até o dia 3; enquanto os animais não suplementados mostraram tal tendência até o dia 2 (quando atingiram o pico). O núcleo homeopático comercial fornecido para os animais durante a gestação e início da lactaçáo resultou em maiores concentraçóes de PT e GLB nas amostras de soro coletadas de ovelhas e cordeiros.

PALAVRAS-CHAVE: Globulina; Homeopatia; Imunoglobulina; Imunidade; Ovino.

'Graduate Program in Animal Bioscience, University of Cuiabá, UNIC, Cuiabá, Mato Grosso, Brazil.

¿Faculty of Veterinary Medicine, Lavras University Center, UNILAVRAS, Lavras, Minas Gerais, Brazil.

Veterinary Medicine Department, Federal University of Lavras, UFLA, Lavras, Minas Gerais, Brazil.

${ }^{4}$ Faculty of Veterinary Medicine, University of Cuiabá, UNIC, Cuiabá, Mato Grosso, Brazil.

${ }^{5}$ Faculty of Veterinary Medicine and Animal Science, São Paulo State University, UNESP, Botucatu, São Paulo, Brazil.

'Department of Veterinary Clinics and Surgery, School of Veterinary, Federal University of Minas Gerais, UFMG, Belo Horizonte, Minas Gerais, Brazil.

'7health and Animal Production Department, Northern University of Paraná, UNOPAR, Arapongas, Brazil.

*Corresponding author: claudiadiasmonteiro@hotmail.com

Received: 16/11/2020. Accepted: 09/02/2021 


\section{INTRODUCTION}

The immunity of lambs in early life is directly associated with their body development. Thus, improved immunity may enable better slaughtering conditions; consequently, it increases the sheep meat production profitability. One of the major concerns about sheep farming in Brazil, as well as in other countries worldwide, lies on the high mortality rate recorded for lambs in their first days of life, fact that decreases production gains (ROOK et al., 1990).

Little is known about the optimal period for colostrum absorption in the bowel of ovine neonates. There have been reports of increased serum immunoglobulin levels when colostrum intake happens in the first hours of life, as well as of significant absorption decrease 24 hours after delivery. It happens due to the intestinal cell maturation process, or rather, because the initial intestinal cells are exchanged by the first generation of mature adult cells, which are characterized by their impermeability to macromolecules (KINDLEIN et al., 2008).

The transfer of maternal antibodies from the ewe to the neonate essentially takes place after delivery through the intestinal absorption of immunoglobulins, which are proteins found in the colostrum (FLAIBAN et al., 2009).

Total serum protein (TP) represents the sum between albumin (ALB) and globulin (GLOB) fractions. Variations in TP levels in newborn animals result from hydration-state fluctuations and, mainly, from the absorption of colostral immunoglobulins (BICUDO et al., 2015). Total protein can be reliably used to help identifying individuals presenting PITF (passive immunity-transfer failure) index (TURQUINO; FLAIBAN; LISBÔA, 2011; ULIAN et al., 2014).

The current scientific literature presents evidences and findings concerning the use of ultra-diluted medications under well-known experimental conditions, just as it does to produce any experimental evidence. It allows understanding the use of and the phenomena involving the method, mainly the ones associated with the immune system and with body defense mechanisms (BELLAVITE et al., 2005).

Studies have already recorded satisfactory responses to the association between homeopathy and reproduction rates, and verminosis, as well as satisfactory immune humoral response to vaccination in sheep (REAL, 2008).

Chabel et al. (2009) concluded that the homeopathic complex applied to ewes has effect on stress, since it reduces serum cortisol concentrations and increases serum antibody concentrations.

The aim of the current study was to investigate the effect of the ingestion of $30 \mathrm{~g}$ of core homeopathic by pregnant and lactating ewes on the body development and serum globulin production in ewes and lambs.

\section{MATERIAL AND METHODS}

\section{Ethical considerations}

The experiment was carried out according to the Animal Welfare Committee of the Faculty of Veterinary Medicine,
University of Cuiabá, Mato Grosso, Brazil (Academic Council Resolution no. 002/2014, CEUA/ UNIC).

\section{Animals, treatments and management}

The study was carried out at a private sheep farm (MS Farm), located at $15^{\circ} 29^{\prime} 06.2^{\prime \prime S} 56^{\circ} 11^{\prime} 20.4^{\prime \prime W}$, which is located in Cuiabá County, MT, during the parturition season (FebruaryApril). The animals were kept in stalls hosting four animals each, in a covered shed; they had access to mineral salt and water ad libitum.

After the 30-day pregnancy was diagnosed through ultrasound examination, pregnant ewes were randomly divided in two groups, namely: the control group comprising nine females supplemented on a daily basis with $300 \mathrm{~g}$ of ovine concentrate containing 16\% of Crude Protein and free of homeopathic complex, during the last four pregnancy and early lactation months; and the treatment group comprising nine females supplemented on a daily basis with $30 \mathrm{~g}$ of homeopathic complex "Homeobase Convert $\mathrm{H}^{\circledR}$ (composition: Natrum muriaticum $10^{-60}$, Calcium carbonicum $10^{-30}$, Silicea terra $10^{-400}$ and Hypothalamus $10^{-30}$ ) (Homeopathic Veterinary Laboratory Real \& Cia Ltda, Campo Grande, MS, Brazil) added and mixed with $300 \mathrm{~g}$ of ovine concentrate containing $16 \%$ of Crude Protein, during the last four pregnancy and early lactation months.

After fully ingesting the concentrate (supplied once a day to the animals in the respective groups), ewes belonging to both experimental groups were fed with bulk (corn silage ad libitum) twice a day. Corn silage leftovers from the previous day were removed in the morning, before the diet was supplied to the animals, the troughs were cleaned and then, the diets were fed to the respective groups.

\section{Body Mass Index (BMI)}

Pregnant animals were subjected to biometric measurements comprising body weight (BW), body condition score (BCS) and body mass index (BMI) to allow monitoring their body development on a monthly basis.

The scoring procedures were always performed by the same technician, according to Radostits et al. (2007).

The body mass index was applied through the equation: $\mathrm{BMI}=\mathrm{BW}$. [(WH.100-1) $\left.\left(\mathrm{SSL} \cdot 100^{-1}\right)\right]^{-1}$, wherein: WH is the withers height; and SSL is the sternum-sciatic length (data expressed in $\mathrm{cm}$ ) (MONTEIRO et al., 2010).

\section{Laboratorial analysis/ \\ serum measurement/ serum analysis}

Blood samples were collected from ewes and lambs through jugular venipuncture, for seven consecutive days after delivery, to allow measuring TP and ALB contents. The samples 
were placed in vacuum tubes, which were kept under refrigeration until they were centrifuged at $1200 \mathrm{x} g$ for 15 minutes in order to separate the supernatant. The resulting serum was kept in a freezer at $-30^{\circ} \mathrm{C}$ until the quantification of TP and ALB contents. After such contents were quantified, their values were subtracted to find the total globulin value (ULIAN et al., 2014).

The biochemical determination of TP and ALB was performed with the aid of the commercial biuret reagent kit for TP (Proteínas Totais Ref.99, Labtest Diagnóstica S.A., Lagoa Santa, MG, Brazil), and of bromocresol green for ALB (Albumina Ref.19, Labtest Diagnóstica S.A., Lagoa Santa, MG, Brazil); the GLB fraction was calculated through the difference between TP and ALB values.

\section{Statistical analysis}

Data were presented by means of descriptive statistics and variables were subjected to ANOVA in the Assistat Statistical software version 7.7 (SILVA; AZEVEDO, 2016). The means of the variables were compared by the Tukey test $(\mathrm{p}<0.05)$.

\section{RESULTS}

Table 1 presents the mean of BW, BCS and BMI of the ewes in both groups, throughout the experimental period.

The analysis applied to the sheep BW data did not show difference between experimental groups ( $p>0.05$ ), whose BW evolution behavior was similar over time, regardless of the experimental group.

As it was previously mentioned, the BCS of the ewes did not present difference ( $p>0.05$ ) between groups or between the herein studied periods. Accordingly, the body mass index BMI $(p>0.05)$ presented behavior similar to that recorded for BW and BCS. The Table 2 presents the mean of BW and BMI of lambs belonging to both groups, during their first seven days of life.

Lamb BW increased as it was expected for body development in their first week of life; there was difference $(p<0.05)$ between evaluated periods (day 1 and day 7 after delivery) and between experimental groups, the group receiving the homeopathic complex showed higher BW increase.

Table 1. Mean \pm standard error of BW (Kg), BCS, and BMl of ewes belonging to the treatment (supplemented with homeopathic complex) and control (without supplementation) groups, during the last four pregnancy and early lactation months.

\begin{tabular}{l|c|c|c}
\multirow{2}{*}{ Groups } & \multicolumn{3}{|c}{ Biometrics } \\
\cline { 2 - 4 } & BW & BCS & BMI \\
\hline Treatment & $51.19 \pm 0.80^{A}$ & $3.06 \pm 0.08^{A}$ & $96.17 \pm 1.97^{A}$ \\
\hline Control & $49.52 \pm 1.01^{A}$ & $2.90 \pm 0.07^{A}$ & $95.15 \pm 1.23^{A}$ \\
\hline
\end{tabular}

Means followed by the different uppercase letter in vertical position did statistically differ from each other by the Tukey test $(p<0.05)$.
Tables 3 and 4 present TP, ALB and GLB concentration values recorded for ewes and lambs, respectively.

The TP and GLB values found in ewes belonging to the treatment group were higher than and different $(\mathrm{p}<0.05)$ from those recorded for the control group. The serum ALB concentration did not differ $(\mathrm{p}>0.05)$ between groups.

The TP, ALB and GLB values recorded for the lambs followed the same pattern as the ones recorded for the ewes. There was difference in TP and GLB $(\mathrm{p}<0.05)$ between groups; the highest values were recorded for the group supplemented with homeopathic complex.

Figure 1 shows TP and GLB evolution in lambs throughout the 7 experimental days. The animals in the treatment group showed trend to present higher TP and GLB values in all experimental periods; supplemented animals showed

Table 2. Mean \pm standard error of $\mathrm{BW}(\mathrm{Kg})$, in the first (day l) and seventh day of life (day 7), and BMl of lambs belonging to the treatment (supplemented with homeopathic complex) and control (without supplementation) groups.

\begin{tabular}{l|c|c|c|c}
\multirow{2}{*}{ Groups } & \multicolumn{4}{|c}{ Biometrics } \\
\cline { 2 - 5 } & BW - day 1 & BW - day 7 & Mean BW & BMI \\
\hline Treatment & $4.50 \pm 0.24$ & $5.98 \pm 0.32$ & $5.24 \pm 0.35^{\mathrm{A}}$ & $41.64 \pm 1.68^{\mathrm{A}}$ \\
\hline Control & $4.03 \pm 0.22$ & $5.10 \pm 0.33$ & $4.56 \pm 0.25^{\mathrm{B}}$ & $37.23 \pm 1.24^{\mathrm{A}}$ \\
\hline Mean & $4.27^{\mathrm{a}}$ & $5.54^{\mathrm{b}}$ & - & - \\
\hline
\end{tabular}

Means followed by the different uppercase letter in vertical position, and by the same lowercase letter in horizontal position, did statistically differ from each other by the Tukey test $(p<0.05)$.

Table 3. Mean \pm standard error of total serum protein, albumin and globulin $(g / d L)$ concentrations of ewes belonging to the treatment (supplemented with homeopathic complex) and control (without supplementation) groups, for seven consecutive days after delivery.

\begin{tabular}{l|c|c|c}
\multirow{2}{*}{ Groups } & \multicolumn{3}{|c}{ Parameters } \\
\cline { 2 - 4 } & $\begin{array}{c}\text { Total serum } \\
\text { protein }\end{array}$ & Albumin & Globulin \\
\hline Treatment & $7.18 \pm 0.17^{\mathrm{A}}$ & $2.33 \pm 0.06^{\mathrm{A}}$ & $4.85 \pm 0.13^{\mathrm{A}}$ \\
\hline Control & $6.60 \pm 0.03^{\mathrm{B}}$ & $2.15 \pm 0.05^{\mathrm{A}}$ & $4.45 \pm 0.06^{\mathrm{B}}$ \\
\hline
\end{tabular}

Means followed by the different uppercase letter in vertical position did statistically differ from each other by the Tukey test $(p<0.05)$.

Table 4. Mean \pm standard error of total serum protein, albumin and globulin $(\mathrm{g} / \mathrm{dL}$ ) concentrations of lambs belonging to the treatment (supplemented with homeopathic complex) and control (without supplementation) groups, for seven consecutive days after delivery.

\begin{tabular}{l|c|c|c}
\multirow{2}{*}{ Groups } & \multicolumn{3}{|c}{ Parameters } \\
\cline { 2 - 4 } & $\begin{array}{c}\text { Total serum } \\
\text { protein }\end{array}$ & Albumin & Globulin \\
\hline Treatment & $6.57 \pm 0.12^{\mathrm{A}}$ & $2.40 \pm 0.03^{\mathrm{A}}$ & $4.17 \pm 0.12^{\mathrm{A}}$ \\
\hline Control & $5.98 \pm 0.10^{\mathrm{B}}$ & $2.34 \pm 0.05^{\mathrm{A}}$ & $3.64 \pm 0.11^{\mathrm{B}}$ \\
\hline
\end{tabular}

Means followed by the different uppercase letter in vertical position did statistically differ from each other by Tukey test $(p<0.05)$. 
trend to progressive increase in both variables until day 3; whereas non-supplemented animals showed such trend until day 2 (the day they reached their peak). After that, the animals presented discrete decrease and stabilization in the values of the two variables, except for GLB in the control group, which showed trend to continuous decrease until the end of the experimental period.

Figure 2 shows TP and GLB evolution in ewes throughout the seven experimental days; the treatment group showed trend to present higher values in both variables in virtually all the experimental periods.

\section{DISCUSSION}

The sheep BW data did not show difference between experimental groups ( $p>0.05)$, can be explained by the fact that the animals presented adequate BW and good body condition score $(\mathrm{BCS}>2.5)$ from the beginning to the end of the experimental period.

Such lack of interaction over time, and regardless of the experimental group, was also reported when the homeopathic product used in the current study was assessed in mice and sheep kept under different feeding regimes (CHABEL et al., 2009). However, several trials conducted with pigs and

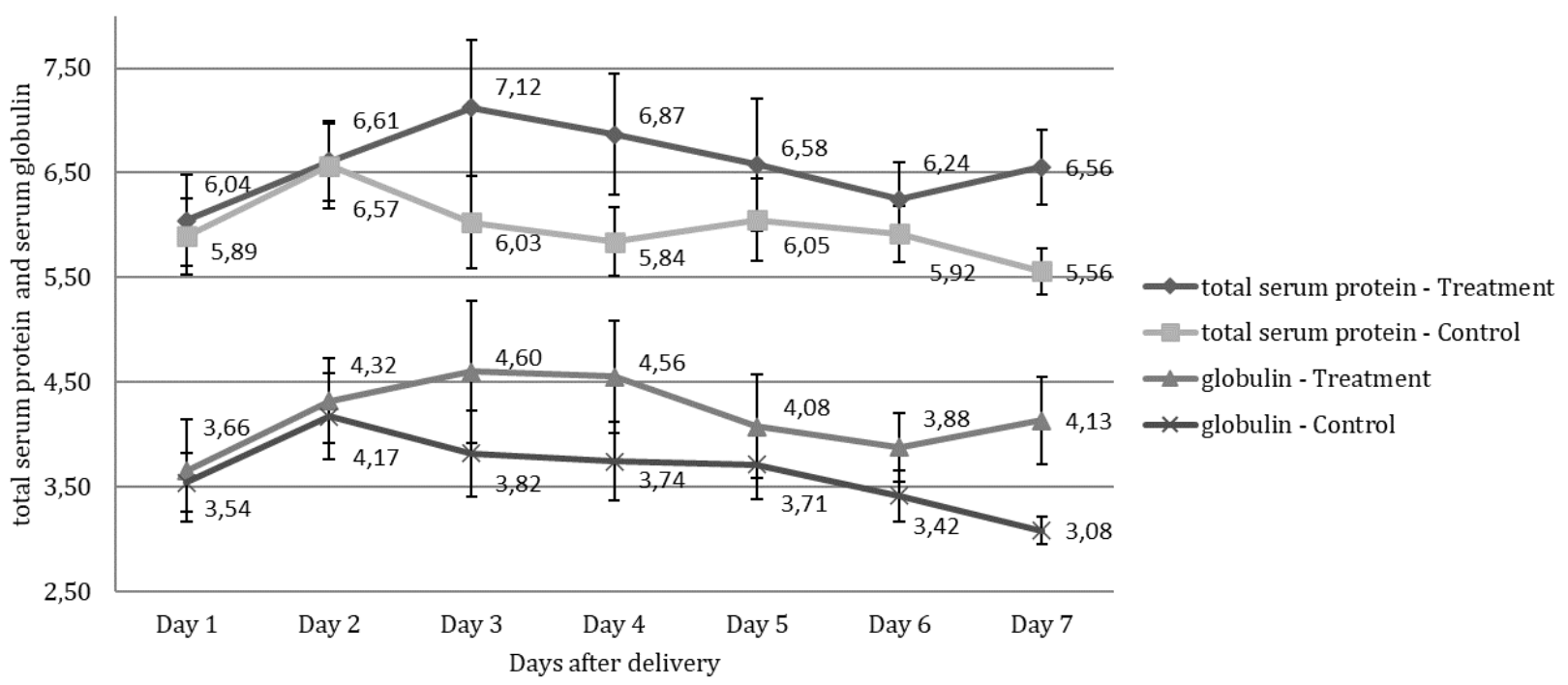

Figure 1. Mean \pm standard error of total serum protein and globulin ( $g / d L)$ concentrations found in lambs belonging to the treatment (supplemented with homeopathic complex) and control (without supplementation) groups, in their first seven days of life.

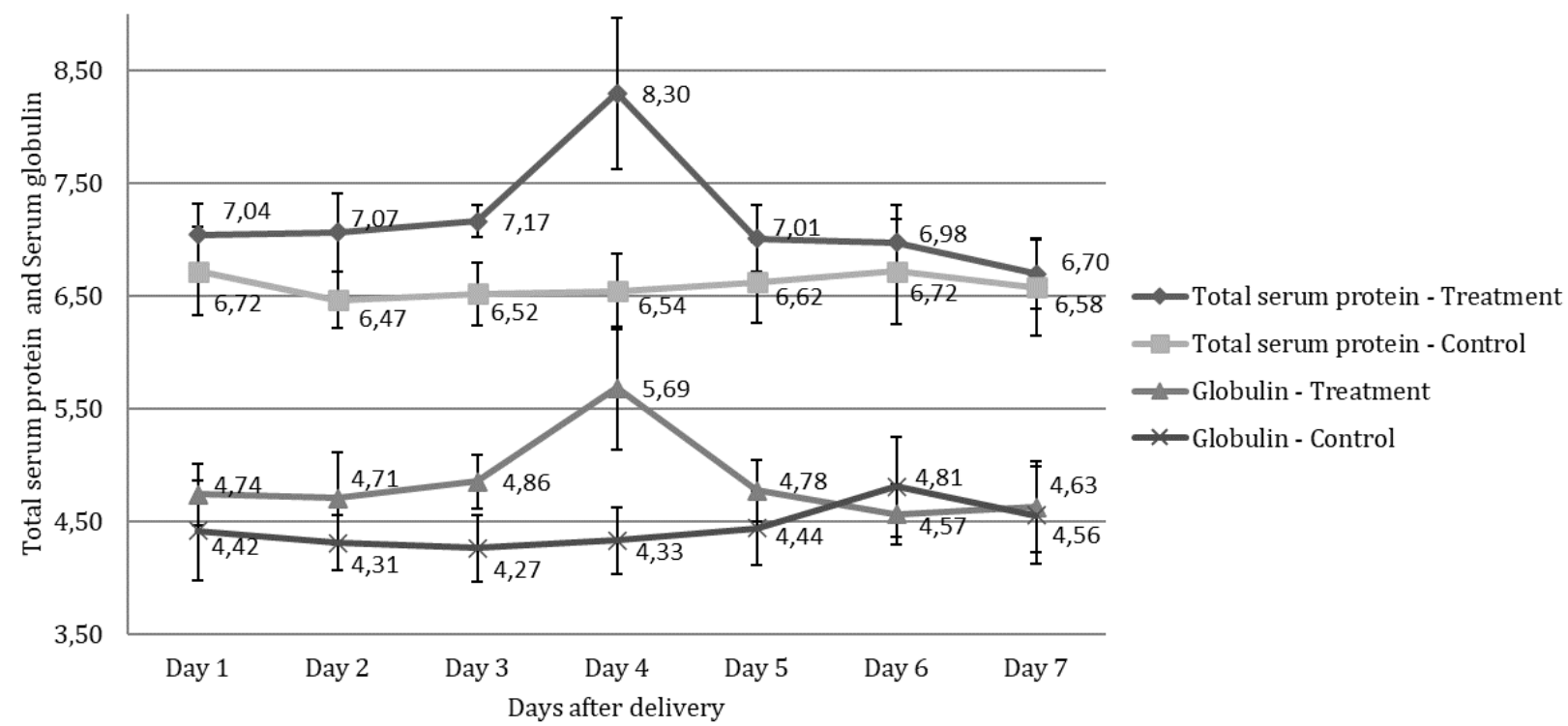

Figure 2. Mean \pm standard error of total serum protein and globulin ( $g / d L)$ concentrations found in ewes belonging to the treatment (supplemented with homeopathic complex) and control (without supplementation) groups, in the first seven days after delivery. 
poultry indicated better effect of homeopathic products on animal performance, when such animals were kept in stressful and deficient production systems (TEIXEIRA et al., 2003). The animals in the current experiment were not subjected to significant management changes or to other stressors, fact that may also explain the lack of statistical difference in BW, BCS and BMI between groups.

The higher BW increase for the lambs in the group receiving the homeopathic complex (Table 2) can be explained through the higher GLB intake by animals belonging to the supplemented group, fact that may have led to the higher development presented by them. Chen et al. (1999) conducted a study on young goats and found that animals presenting adequate passive immunity transfer at higher concentrations also showed higher weight gain and BW in their first five days of life.

The measurement of total protein in the blood serum was the method herein adopted to assess passive immunity transfer in lambs; results showed positive correlation (>88\%) between TP and immunoglobulin concentrations (FÉRES et al., 2010; ULIAN et al., 2014). In the present study the difference in TP and GLB between groups for the lambs can be explained by the better immunity transfer recorded for supplemented mothers belonging to the treatment group, which presented higher TP and GLB ( $\mathrm{p}<0.05)$ concentrations and, consequently, better-quality colostrum than females belonging to the control group.

Chabel et al. (2009) conducted a study with rabies primovaccinated sheep receiving the same homeopathic complex used in the current study and found significant superiority in serum antibody titers against rabies. In addition, the aforementioned authors recorded slight longevity in these values for sheep subjected to homeopathic treatment in comparison to the non-homeopathically-treated ones. Thus, the superiority of TP and GLB values found in the supplemented ewes, and in their respective offspring, may be explained by the increased GLB concentrations in the mothers, mainly the immunoglobulins, which were passed to the lambs through the colostrum by means of the passive immunity transfer, mainly in the supplemented group.

According to Bicudo et al. (2015), the TP concentration reflects the amount of ALB and GLB, and it can be used to monitor possible failures in the passive immunity transfer process. The passive immunity transfer may be considered adequate in the present study, since the TP values $(5.98 \pm 0.10$ in the control group and $6.57 \pm 0.12$ in the treatment group), which can be used as immunity transfer indicators in lambs, were higher than $5.4 \mathrm{~g} / \mathrm{dL}$. According to O'Brien; Sherman (1993), $5.4 \mathrm{~g} / \mathrm{dL}$ is the appropriate minimum reference value. As per Bicudo et al. (2015) and Ahmad et al. (2000), total protein concentrations lower than $5.0 \mathrm{~g} / \mathrm{dL}$ in 24-hour-old animals indicate hypogammaglobulinemia. According to Turquino; Flaiban; Lisbôa (2010) and Ulian et al. (2014),
TP values ranging from 5.1 to $6.0 \mathrm{~g} / \mathrm{dL}$ may indicate partial passive immunity transfer failure, whereas values lower than or equal to $5 \mathrm{~g} / \mathrm{dL}$ may indicate total passive immunity transfer failure in lambs.

The herein recorded TP concentrations were lower than those found by Chen et al. (1999) in goats $(9.4 \mathrm{~g} / \mathrm{dL}$ at birth), than total protein values found by Bekele; Otesile; Kasali (1992) in 48-hour-old lambs ( $8.39 \mathrm{~g} / \mathrm{dL})$, as well as than values recorded by Féres et al. (2010) $(7.6 \mathrm{~g} / \mathrm{dL})$ in lambs. However, they were similar to values found by Bicudo et al. (2015) in 6-hour-old and in 3-day-old sheep $(6.8 \mathrm{~g} / \mathrm{dL})$, and higher than those found by Ulian et al. (2014) in 24- and 48-hourold sheep (mean values 5.68 and $5.61 \mathrm{~g} / \mathrm{dL}$, respectively).

The values recorded for GLB concentration in lambs throughout the first seven consecutive days after delivery can be considered adequate, as well as close to those observed by Bekele; Otesile; Kasali (1992), Bicudo et al. (2015), and Ulian et al. (2014), who recorded mean serum GLB $3.96 \mathrm{~g} / \mathrm{dL}$, $4.0 \mathrm{~g} / \mathrm{dL}$ and $4.05 \mathrm{~g} / \mathrm{dL}$, respectively.

On the other hand, the serum ALB values recorded for ewes and lambs were within the reference values set by Feldman; Zinkl; Jain (2000); however, the value recorded for lambs was lower than the value $(2.8 \mathrm{~g} / \mathrm{dL})$ found by Bicudo et al. (2015) and above the one $(1.75 \mathrm{~g} / \mathrm{dL})$ recorded by Ulian et al. (2014).

The reduced TP and GLB values after day 2 in the control group, and after day 3 in the treatment group, were expected, since they had been already recorded by Ulian et al. (2014), Costa (2013), and O'Brien; Sherman (1993). It happened due to the colostrum-milk transition, which reduced the amount of colostral protein and was mainly represented by immunoglobulins. Such reduction affected the serum amount in the lambs, which found lower colostrum supply in the transition milk and, consequently, presented lower absorption, besides the estimated intestinal villi closure time in newborn animals (CHEN et al., 1999; DONOVAN et al., 1986).

There are differences in the TP, GLB and immunoglobulin peak days in newborn animals, as well as in the maximum values they reach, partly because of differences between species and between adopted methodologies. Changes in TP concentrations recorded by Chen et al. (1999) in goats showed similar behavior (parallelism) in serum globulin concentrations measured after delivery. Similar result was also recorded by Donovan et al. (1986) in calves. This is the reason why the TP content in the neonatal serum was used as passive immunity transfer index by the aforementioned authors, as well as in the present study.

Such TP and GLB behavior throughout the experiment, both in ewes and in lambs, could be explained by the use of homeopathic complex, which is capable of increasing the production and longevity of antibodies, thus triggering physiological changes capable of improving animal performance (CHABEL et al., 2009; VARSHNEY; NARESH, 2005), fact that justifies the TP, GLB, weight gain and live weight results recorded in the current study. 


\section{CONCLUSIONS}

The commercial core homeopathic supplied to ewes (30 g/ani$\mathrm{mal} /$ day) during pregnancy and early lactation led to higher TP and GLB concentrations of ewes and their lambs, for seven consecutive days after delivery.

\section{ACKNOWLEDGEMENTS}

The authors are grateful to Fazenda MS for making animals available to participate in the experiment, UNIC for the support during the research, and Coordination for Improvement of Higher Education Personnel (CAPES, Brazil, grant PNPD number 2013/2856).

\section{REFERENCES}

AHMAD, R. et al. The level of immunoglobulins in relation to neonatal lamb mortality in Pak-Karakul sheep. Veterinarski Arhiv, v. 70, п.3, p. 129-139, 2000.

BICUDO, L. et al. Monitoring of acquisition of passive immunity in lambs with voluntary colostrum intake by determining the serum total protein. Veterinária e Zootecnia, v. 22, n. 3, p. 437-444, 2015.

BEKELE, T.; OTESILE, E. B.; KASALI, O. B. Influence of passively acquired colostral immunity on neonatal lamb mortality in Ethiopian highland sheep. Small Ruminants Research, v. 9, n. 3, p. 209215, 1992.

BELLAVITE, P. et al. Immunology and homeopathy. Historical background. Evidence-Based Complementary and Alternative Medicine, v. 2, p. 44l-452, 2005.

CHABEL, J. C. et al. Effect of a homeopathic complex "Convert Homeobase $\mathrm{H}^{\otimes \prime}$ in sheep under conditions of food restriction. Brazilian Journal of Veterinary Research and Animal Science, v. 46, n. 5, p. 412-423, 2009.

CHEN, J. C. et al. Serum protein levels and neonatal growth rate of Nubian goat kids in Taiwan area. Small Ruminants Research, v. 32, п. 2, p. 153-160, 1999.

COSTA, J. N. et al. Failure of passive immunity transfer in crossbred lambs (Santa Inês x Dorper) and proteinogram study from birth until waned. Brazilian Journal of Veterinary Research and Animal Science, v. 50, n. 2, p. 114-120, 2013.

DONOVAN, G. A. et al. Factors influencing passive transfer in dairy calves. Journal of Dairy Science, v. 69, n. 3, p. 754-759, 1986.

FLAIBAN, K. K. M. C. et al. Transfer of passive immunity in lambs whose mothers received diets with different levels of energy or protein in the final third of gestation. Ciência Animal Brasileira, v. I, p. 181-185, 2009.

FELDMAN, B. F.; ZINKL, J. G.; JAIN, N. C. Schalm's Veterinary Hematology. 5. ed. Philadelphia: Lippincott Williams and Wilkins, 2000. 1344 p.

FERES, F. C. et al. Passive transfer immunity valuation in lambs with until 30 days of life. Brazilian Journal of Veterinary Research and Animal Science, v. 47, n. 3, p. 231-236, 2010.
KINDLEIN, L. et al. Effects of enriched colostrum supply in intestinal mucosa morphology of newborn calves. Acta ScientiaeVeterinariae, v. 36, p. 31-34, 2008.

MONTEIRO, C. D. et al. Medroxyprogesterone acetate or longacting progesterone in the biostimulation of lambs. Italian Journal Animal Science, v. 9, n. 64, p. 344-347, 2010.

O'BRIEN, J. P.; SHERMAN, D. M. Serum immunoglobulin concentrations of newborn goat kids and subsequent kid survival through weaning. Small Ruminants Research, v. 1l, n. 1, p. 7l-77, 1993.

RADOSTITS, O. M. et al. Veterinary Medicine: A textbook of the diseases of cattle, horses, sheep, pigs and goats. 10th ed. Philadelphia: W. B. Saunders; 2007. 2065 p.

ROOK, J. S. et al. Diagnosis and control of neonatal losses in sheep. Veterinary Clinics of North America: Food Animal Practice, v. 6, ก. 3, p. 531-562, 1990.

REAL, C. M. Population Homeopathy - Fundamentals, Breaking a Paradigm. Hora Veterinária, v. 28, p. 13-20, 2008.

SILVA, F. A. S.; AZEVEDO, C. A. V. The Assistat Software Version 7.7 and its use in the analysis of experimental data. African Journal of. Agricultural Research, v. 11, n. 39, p. 3733-3740, 2016.

TEIXEIRA, M. A. et al. Effect of a biostimulatory homeopathic complex on mice subjected to feed stress. In: INTERNATIONAL CONGRESS ON THE FUTURE OF ANIMAL RESEARCH, 1., 2003, Rio de Janeiro. Proceedings... Rio de Janeiro: Fiocruz; 2003. p. 56.

TURQUINO, C. F.; FLAIBAN, K. K. M. C.; LISBÔA, J. A. N. Passive transfer of immunity in meat lambs reared in the tropics on extensive management. Pesquisa Veterinária Brasileira, v. 31 , n. 3, p. 199-205, 2011.

ULIAN, C. M. V. et al. Evaluation of colostral absorption in neonates of Bergamacia breed. Arquivo Brasileiro de Medicina Veterinária e Zootecnia, v. 66, n. 3, p. 705-712, 2014

VARSHNEY, J. P.; NARESH, R. Comparative efficacy of homeopathic and allopathic systems of medicine in the management of clinical mastitis of Indian dairy cows. Homeopathy, v. 94, n. 2, p. 81-85, 2014. 